\title{
Editorial \\ Diversifying the Landscape with Animal Integration: An Introduction to the Environmental Sustainability of Crop-Livestock Systems
}

\author{
Kathleen Delate ${ }^{1, *}$ and Bradley J. Heins ${ }^{2}$ (D) \\ 1 Department of Agronomy and Horticulture, Iowa State University, 716 Farm House Lane, \\ Ames, IA 50011, USA \\ 2 West Central Research and Outreach Center, University of Minnesota, 46352 MN-329, \\ Morris, MN 56267, USA; hein0106@umn.edu \\ * Correspondence: kdelate@iastate.edu; Tel.: +1-515-294-7069
}

Citation: Delate, K.; Heins, B.J. Diversifying the Landscape with Animal Integration: An Introduction to the Environmental Sustainability of Crop-Livestock Systems. Agronomy 2021, 11, 140. https://doi.org/ 10.3390/agronomy11010140

Received: 25 December 2020 Accepted: 30 December 2020 Published: 13 January 2021

Publisher's Note: MDPI stays neutral with regard to jurisdictional clai$\mathrm{ms}$ in published maps and institutional affiliations.

Copyright: (C) 2021 by the authors. Licensee MDPI, Basel, Switzerland. This article is an open access article distributed under the terms and conditions of the Creative Commons Attribution (CC BY) license (https:// creativecommons.org/licenses/by/ $4.0 /)$.
In this Special Issue of "Environmental Sustainability of Crop-Livestock Systems," we collected eleven articles that represent a wide breadth of integrated systems around the world, including the U.S., Canada, Uruguay, Colombia, Spain, South Africa, and Portugal. In "The 'Palo a Pique' Long-Term Research Platform: First 25 Years of a CropLivestock Experiment in Uruguay" by Pablo Rovira et al. [1], we learn about a 25-year-old Long-Term Experiment (LTE) evaluating different pasture-crop rotations under livestock grazing. Results from this experiment demonstrated that the rotation of perennial pastures of grasses and legumes with crops was essential in mitigating soil carbon losses. This long-term-experiment lays the necessary groundwork to address the role of ruminants in climate change, competition for land, nutrient dynamics, and food security in today's society and the future. The article "Estimation of Soil Loss Tolerance in Olive Groves as an Indicator of Sustainability: The Case of the Estepa Region (Andalusia, Spain)" by Antonio Alberto Rodríguez Sousa et al. [2] explores the sustainability of olive groves in Andalusia, Spain, where soil erosion is a serious impediment to optimal productivity. Because animals have been known to graze under these food-producing trees, the authors evaluated soil loss and its role in ecosystem sustainability. Two indices-the Soil Loss Tolerance Index (SLTI) for nonspecific crops and a Soil Loss Tolerance Index corresponding to the Estepa region (SLTIlog)-were utilized. Using two unique indices can inform the adoption of management measures to maintain productivity while supporting conservation and ecosystem services. The article on "Clipping Forage Sorghum Twice and Nitrogen Topdressing Offer an Option for Dual-Purpose Use for Cover Cropping and Fodder in Mixed Crop/Livestock Farming Systems" by Kudzayi Janhi et al. [3] highlights the use of sorghum as a diverse crop that can supply animal nutrition and help mitigate soil erosion as a cover crop. The experiment varied the number of sorghum clippings and supplemental nitrogen applications to determine the root biomass and crude protein changes. Results showed that clipping twice and $\mathrm{N}$ topdressing was the best management practice for the dual-purpose of soil cover and livestock feed. In the "Nutritional Quality of Plant Species in Pyrenean Hay Meadows of High Diversity" by Ramón Reiné et al. [4], the feed quality of 34 species of vegetation present in the Pyrenean mountain hay meadows subject to extensive management is analyzed in this article. Results showed that all species presented suitable mineral content, with the exception of phosphorus, and some species proved exceptional in their forage feed value. Soil analysis showed that most species are growing under N-limited conditions, which is sufficient for their conservation in meadows. The article "Fatty Acid Composition Dynamics of Rye (Secale cereale L.) and Wheat (Triticum aestivum L.) Forages under Cattle Grazing" by Hannah N. Phillips et al. [5] investigates the fatty acid compositions of fall-planted rye and wheat forages while rotationally grazed by steers. Results from the study show that fatty acid composition had more variation in 
wheat than rye over the course of the grazing interval. The fatty acid compositions varied based on the length of the grazing and the forage species, suggesting possible adjustments to grazing schedules to better manage the dietary fatty acid intake of grazing cattle.

In the article "Cropping System and Rotational Grazing Effects on Soil Fertility and Enzymatic Activity in an Integrated Organic Crop-Livestock System" written by Fernando Shintate Galindo et al. [6], the effects of alternative grazing systems on soil fertility and enzyme activity are examined. Results of the experiment suggest that rotational grazing can lead to more rapid nutrient cycling and increase soil quality under a pasture-wheat/vetchcorn-pasture cropping system, which showed greater response than the pasture-ryesoybean-pasture system. These results show promise for producers who aim to diversity their farming operation and reduce the need for external inputs. The article "Soil Carbon Dynamics under Pastures in Andean Socio-Ecosystems of Colombia" by María-Cristina Ordoñez et al. [7] explores the mechanisms and speed at which soil organic carbon (SOC) is accumulated in pastures. Results indicated that, in natural pasture soil, diversifying organic inputs promoted the growth of microbial biomass and metabolic efficiency, while intensive management had adverse effects on SOC. This study shows that understanding soil processes and adapting agricultural management could allow for greater SOC storage, while improving pasture quality. In "Evaluating Dry Matter Production and Grain Yield of Dual-Purpose Winter Wheat Using Field Experiment and Modelling" by Ketema Tilahun Zeleke [8], the potential of 'Wedgetail' winter wheat to provide grazing and grain yield under various conditions in Australia was analyzed. The experiment involved variations in sowing times, grazing times, and watering regimes under present and future climate scenarios. The results showed that the yield was not significantly responsive to the time of sowing, but earlier sowing times would reap more benefits, but grazing earlier was not significantly different from grazing only once towards the end of the grazing period. The article "Evolution of Hay Meadows between 1956, 1986, and 2016 and Its Relation to the Characteristics and Location of the Parcels in the Valley of the River Esera (Pyrenees, Spain)" written by Joaquín Ascaso et al. [9] addresses changes occurring in the hay meadows of the Ésera river valley of the central Pyrenees in Spain. Because the European Union has established measures aimed at maintaining agro-livestock activity and the conservation of hay meadows through the Common Agricultural Policy (CAP), it is important to document ecological changes to this area over time. From 1986 to 2016, the area of meadows was reduced, along with the number of livestock holdings, and a transformation to pastures, forests, and urbanized land.

In "Forage Yield and Nutritive Value of Cool-Season and Warm-Season Forages for Grazing Organic Dairy Cattle," Ritz et al. [10] compared the nutritive value of warmseason annual grasses, along with cool-season perennial grasses and legumes, as dairy cow forages. A combination of perennial ryegrass (Lolium perenne L.), orchardgrass (Dactylis glomerata L.), meadow bromegrass (Bromus riparius Rehmann), meadow fescue (Schedonorus pratensis (Huds.) P. Beauv), alfalfa (Medicago sativa L.), white clover (Trifolium repens L.), red clover (Trifolium pratense L.), and chicory (Cichorium intybus) yielded 39\% more forage than sorghum-sudangrass (Sorghum bicolor (L.) Moench subsp. drummondii [Steud.]) and teff (Eragrostis tef L.) pastures. Total tract NDF digestibility varied by month and year across the study, suggesting that weather may be the most critical factor in determining the forage nutritive value of these grasses and legumes. In "Climate Change Impacts on Irrigation Requirements of Preserved Forage for Horses under Mediterranean Conditions," Soares et al. [11] discuss alarming statistics on how climate change in Portugal, specifically drought, will cause a 38-67\% increase in irrigation requirements for pasture and forage production, consisting primarily of Italian ryegrass (Lolium multiflorum Lam.) and Persian clover (Trifolium resupinatum L.), under current high-production scenarios. Reducing the number of harvests for preserved forage, or producing forage on low-lying areas, can ameliorate this problem in the near-term.

In conclusion, we hope readers will appreciate the numerous benefits of animal integration articulated in this Special Issue from cropping systems around the world. 
Particularly in this time of rapid climate change, integrated systems hold the most promise for mitigating soil carbon losses and preserving agro-biodiversity as a buffer against climate-related shocks and food insecurity.

Funding: This work is supported by Organic Agriculture Research and Extension Initiative [grant no. 2014-51300-22541/ project accession no. 1003975] from the USDA National Institute of Food and Agriculture.

Conflicts of Interest: The authors declare no conflict of interest.

\section{References}

1. Rovira, P.; Ayala, W.; Terra, J.; García-Préchac, F.; Harris, P.; Lee, M.R.F.; Rivero, M.J. The 'Palo a Pique' Long-Term Research Platform: First 25 Years of a Crop-Livestock Experiment in Uruguay. Agronomy 2020, 10, 441. [CrossRef]

2. Rodríguez Sousa, A.A.; Barandica, J.M.; Rescia, A.J. Estimation of Soil Loss Tolerance in Olive Groves as an Indicator of Sustainability: The Case of the Estepa Region (Andalusia, Spain). Agronomy 2019, 9, 785. [CrossRef]

3. Janhi, K.; Matshaya, Z.; Chiduza, C.; Muzangwa, L. Clipping Forage Sorghum Twice and Nitrogen Topdressing Offer an Option for Dual-Purpose Use for Cover Cropping and Fodder in Mixed Crop/Livestock Farming Systems. Agronomy 2020, 10, 17. [CrossRef]

4. Reiné, R.; Ascaso, J.; Barrantes, O. Nutritional Quality of Plant Species in Pyrenean Hay Meadows of High Diversity. Agronomy 2020, 10, 883. [CrossRef]

5. Phillips, H.N.; Heins, B.J; Delate, K.; Turnbull, R. Fatty Acid Composition Dynamics of Rye (Secale Cereale L.) and Wheat (Triticum Aestivum L.) Forages under Cattle Grazing. Agronomy 2020, 10, 813. [CrossRef]

6. Galindo, F.S.; Delate, K.; Heins, B.; Phillips, H.; Smith, A.; Pagliari, P.H. Cropping System and Rotational Grazing Effects on Soil Fertility and Enzymatic Activity in an Integrated Organic Crop-Livestock System. Agronomy 2020, 10, 803. [CrossRef]

7. Ordoñez, M.-C.; Casanova Olaya, J.F.; Galicia, L.; Figueroa, A. Soil Carbon Dynamics under Pastures in Andean Socio-Ecosystems of Colombia. Agronomy 2020, 10, 507. [CrossRef]

8. Zeleke, K.T. Evaluating Dry Matter Production and Grain Yield of Dual-Purpose Winter Wheat Using Field Experiment and Modelling. Agronomy 2020, 10, 338. [CrossRef]

9. Ascaso, J.; Reiné, R.; Barrantes, O. Evolution of Hay Meadows between 1956, 1986, and 2016 and Its Relation to the Characteristics and Location of the Parcels in the Valley of the River Esera (Pyrenees, Spain). Agronomy 2020, 10, 329. [CrossRef]

10. Ritz, K.E.; Heins, B.J.; Moon, R.; Sheaffer, C.; Weyers, S.L. Forage Yield and Nutritive Value of Cool-Season and Warm-Season Forages for Grazing Organic Dairy Cattle. Agronomy 2020, 10, 1963. [CrossRef]

11. Soares, D.; Rolim, J.; Fradinho, M.J.; Paço, T.A. Climate Change Impacts on Irrigation Requirements of Preserved Forage for Horses under Mediterranean Conditions. Agronomy 2020, 10, 1758. [CrossRef] 